\title{
Implementation of Interleaved Three Stage Boost Converter Fed Dc Drive With Zero-Voltage Transition
}

\author{
Aarthi Suriya, Anithasampathkumar, S.Sherine
}

\begin{abstract}
This paper manages reenactment of Voltage Controlled PFC based interleaved support Converter sustained DC engine Drive in open circle. An epic delicate exchanging interleaved coupled-inductor support converter is proposed in this paper. Just a solitary dynamic delicate exchanging module is expected to all the while accomplish the delicate exchanging property of the two switches in the interleaved coupled-inductor support converter. The better productivity is accomplished with the less segments and cost. The two principle switches can accomplish the ZVT turn-on and littler current mood killer at the same time when the single dynamic delicate exchanging module is dynamic. The aftereffects of three phase ILBC are contrasted and those of two phase ILBC.. [1],[3],[5]
\end{abstract}

Keywords : Interleaved Converter; Voltage Multiplier; Mixed signal processor; Photo voltaic System; Feedback control.

\section{INTRODUCTION}

Coupled-inductor interleaved help converters are being worked on for high-current, high-control applications running from car to circulated age. The working methods of these coupled-inductor converters can be mind boggling. This paper introduces an examination of the different consistent current (CCM) and broken current (DCM) methods of activity of the coupled-inductor interleaved two-stage help converter.

The irregular current mode lift power factor correction (PFC) converter subsequently achieves PFC when the commitment cycle is kept predictable in a line cycle; in any case, there is colossal third symphonious in the data current, and the third consonant has the hidden time of $\pi$ in respect of the basic part. [2 ],[ 4],[6]

Likewise, the stock voltage waveform gets mutilated as a result of the responsive current thus an EMC issue occurs, for a mechanical assembly, delicate to such voltage bending. Additionally, this cumulates advantageous misfortunes and

Revised Manuscript Received on July 22, 2019

S.Aarthi Suriya , Department of EEE,Bharath Institute of Higher Education and Research, Tamilnadu, India. Email: aarthisuriya2703@gmail.com

Anitha Sampathkumar, Department of EEE,Bharath Institute of Higher Education and Research, Tamilnadu, India. Email: anithababs@gmail.com

S.Sherine, Department of EEE,Bharath Institute of Higher Education and Research, Tamilnadu, India. Email: nssherine@gmail.com dielectric worries in capacitors and links because of the consonant substance and thus the expansion in flows in windings of pivoting apparatus and transformers and clamor in different items, and removing from untimely disappointment of circuits and security modules. Essential Distributed Power System of ILBC is showed up in Fig 1.

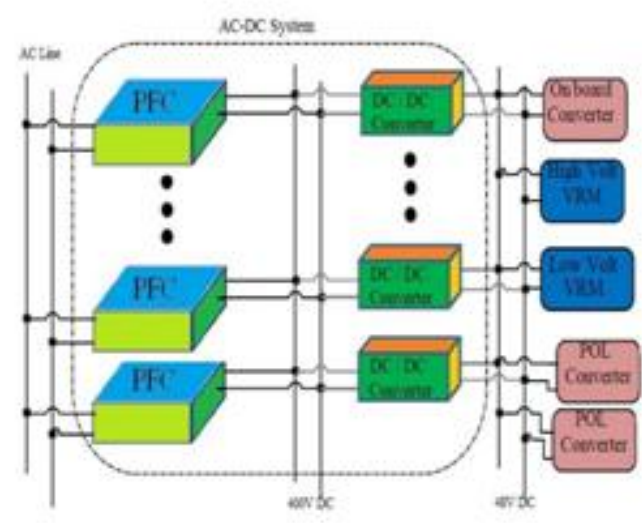

Fig. 1: Block Diagram of Basic Distributed Power System

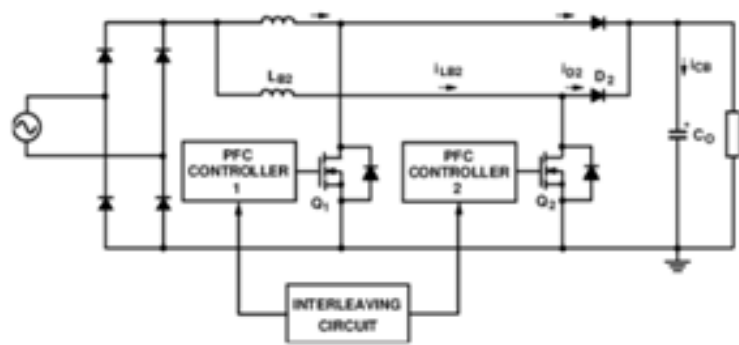

FIG 1.1. ESSENTIAL TOPOLOGY OF TWO INTERLEAVED PFC HELP CONVERTERS.

Along these lines, Basic topology of two interleaved PFC bolster converters is showed up in Fig 1.1. The information power factor is low, and a colossal storing capacitor is required. Imbuing legitimate third symphonious with starting time of zero into the data current could diminish the limit capacitor. This paper proposes the variable commitment cycle control to implant the required third 
symphonious into the data current to meet the essential of IEC 61000-3-2 Class D or Energy Star. A technique for fitting the commitment cycle is moreover proposed for revising the circuit execution.

Issue finding framework for a staggered inverter utilizing a chief part neural system is proposed in this section. Thusly, a neural N/W grouping is applied to the shortcoming determination of a MLID framework. A lower dimensional info space will likewise for the most part lessen the time important to prepare a neural system, and the decreased commotion may improve the mapping execution is displayed by Tolbert [01]-2007. New control techniques are portrayed including both joint and separate control of the individual three-level inverters is proposed by Peng [02]-2004.

Staggered converters-An empowering innovation for high-control applications is given by Rodriguez. This paper fills in as a prologue to the subject for the not-acquainted peruser, just as an update or reference for scholastics and rehearsing designers working in the field of modern and power electronics[03]-2009.A summed up staggered inverter topology with self voltage adjusting is displayed by Peng. This work exhibits a summed up staggered inverter (converter) topology with self voltage adjusting [04]-2004. The Circuit Diagram of the Operating Modes of Three Phase Interleaved Boost Converter is appeared in Fig 2.

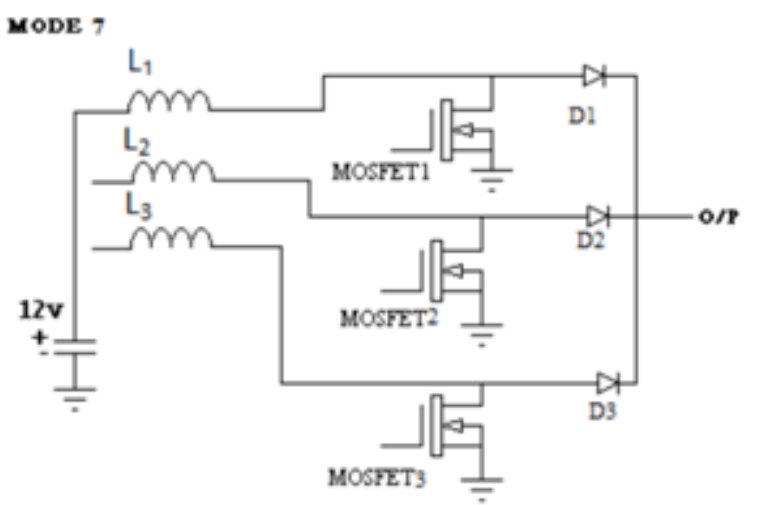

Fig 2 Circuit Diagram of the Operating Modes of Three Phase Interleaved Boost Converter

Greatest power point following in a one-cycle-controlled single-arrange photovoltaic inverter is recommended by Fortunato. Structure requirements that record for various climate conditions are embraced. The improvement calculation additionally gives valuable data concerning the framework affectability regarding every one of the controller parameters[5]-2008. A Survey on fell staggered inverters is given by Gopakumar. This trademark enables one to accomplish astounding yield voltages and information flows and furthermore extraordinary accessibility because of their inborn part repetition. [6]-2010. Decoupled control framework for fell h-connect staggered converter based STATCOM is exhibited by Farivar. In this work, first, the conditions that dispose of this coupling impact are inferred, and afterward, a control framework that authorizes the determined decoupling conditions is proposed[7]-2015.

Measured Multilevel Inverter with New Modulation Method and Its Application to Photovoltaic Grid-Connected Generator is proposed by Jun[8]-2016. Secluded Cascaded H-Bridge Multilevel PV inverter with disseminated MPPT for lattice associated applications is given by Bailu. To illuminate this issue, a control conspire with balance remuneration is additionally proposed[9]-2014. A devoted P\&O MPPT licenses to control autonomously the voltage of every dc-connect; along these lines, expanding the power extraction even in jumbled conditions[10]-2015.

Secluded staggered inverter with new adjustment technique and its application to photovoltaic network associated generator is proposed by Mei. This new adjustment strategy depends on specific virtual circle mapping, to accomplish dynamic capacitor voltage balance without the assistance of an additional pay signal[11]-2013.A Generalized Cascaded Multilevel Inverter Using Series Connection of Sub- Multilevel Inverters is given by Kangarlu. [7],[ 9] ,[11]

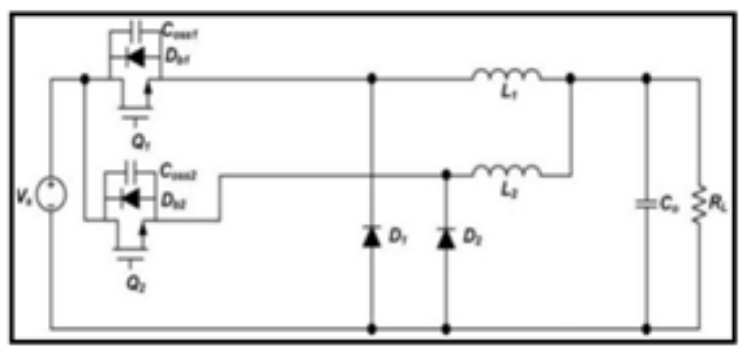

Fig 3 ILBC general structure

An ILBC typically coordinates in excess of two regular topologies, and in a similar power condition, the current in the component of an ILBC is half of that of the ordinary topology. To decrease the exchanging misfortunes of the high recurrence exchanging, single buck converter can utilize either zero-voltage exchanging (ZVS) or potentially zero-current exchanging (ZCS). Because of basic structure and low control multifaceted nature an interleaved buck converter (ILBC) has gotten a great deal of consideration, in applications where high yield current with low swell and venture down change proportion are required.

Be that as it may, in the customary ILBC appeared in Figure 3. The high evaluated voltage gadgets on high the info voltage ought to be utilized since all the semiconductor gadgets suffer from the information voltage. [8],[10] ,[12]

Utilization of staggered inverters for a higher power reason in enterprises has turned out to be progressively mainstream. This is incompletely a result of top notch yield waveform of staggered inverters in correlation with two-level inverters[12]-2013.Analysis, control and plan of half breed Grid associated inverter for sustainable power source age with power quality molding is displayed by Wang [13]-2017. 
THD in Cascade Multilevel Inverter Symmetric and Asymmetric is proposed by Vargas. This work revolves around the close to examination of fell amazed inverter whit two inverter cells, symmetric (5 levels) and unbalanced (7 and 9 levels). These inverters are executed without changes in the Power Semiconductor Devices, simply adjust the control stage and data supply voltages in the cells[14]-2011.

Another framework associated PV framework dependent on fell $\mathrm{H}$-connect semi z source inverter is given by Dongsen. Another plan for network associated photovoltaic (PV) interface by blend of a semi $\mathrm{Z}$ source inverter (qZSI) into fell $\mathrm{H}$-connect $(\mathrm{CHB})$ is proposed in this work. The proposed plan empowers PV string voltage lift to a higher level, and takes care of the lopsidedness issue of DC-connect voltage in customary CHB inverters[15]-2013.

Another lattice associated PV framework dependent on fell H-connect semi z source inverter is exhibited by Peng. Another plan for matrix associated photovoltaic (PV) interface by blend of a semi Z source inverter (qZSI) into fell $\mathrm{H}$-connect (CHB) is proposed in this work[16]-2012. The above writing doesn't manage the examination of two phase and three phase ILBC frameworks. [13], [15] ,[ 17]

\section{SYSTEM DESCRIPTION}

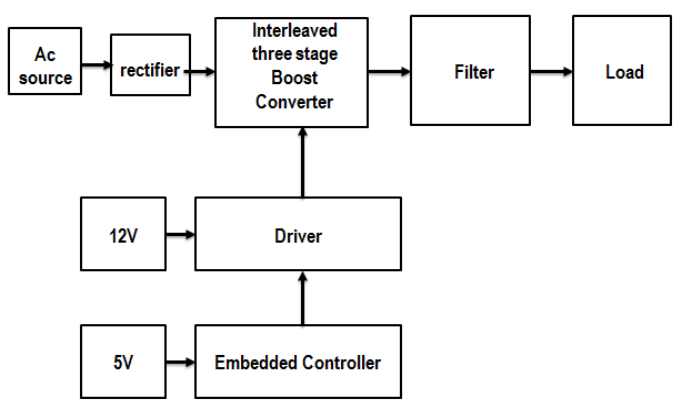

Fig 4 Block Diagram of three stage ILBC

\section{DESIGN CALCULATIONS}

Specifications

Input Voltage, $\mathrm{Vi}=12 \mathrm{~V}$, Output Voltage, $\mathrm{Vo}=48 \mathrm{~V}$

Switching Frequency, fs $=5 \mathrm{kHz}$, Ripple current, $\Delta \mathrm{I}=3$ $\mathrm{mA}$, Resistance from LV side, R' $=0.65 \mathrm{Ohms}$, Duty Cycle, $\mathrm{D}=0.75$.

With the above data, the values of inductance, $\mathrm{L}$ and Capacitance $\mathrm{C}$ are calculated with the following formulae

$$
\begin{aligned}
& \mathrm{L}=\left(\mathrm{V}_{\mathrm{i}} \mathrm{i} \mathrm{D}\right) /(\mathrm{f} \Delta \mathrm{I}) \\
& \mathrm{C}=\mathrm{D} /\left(2 \mathrm{fR}^{\wedge}\right)
\end{aligned}
$$

The boost inductance works out to be $600 \mathrm{mH}$ and the capacitance works out to be $115 \mu \mathrm{F}$.

For $50 \mathrm{~Hz}$ frequency of the inverter, the time period works out to be $20 \mathrm{~ms}$. There are eight operating states in each cycle. The time period of each state is $2.5 \mathrm{~ms}$.

\section{Simulation Results}

Interleaved two Stage Boost Converter Fed DC Drive With Zero-Voltage Transition Circuit chart is showed up in Fig.5. Info voltage crosswise over two phase ILBC is showed up in Fig 6 and its worth is 12.3V. Exchanging beat for ILBC M1 and M3 is showed up in Fig 7 and its worth is $1 \mathrm{~V}$. Yield voltage crosswise over two phase ILBC is showed up in Fig 8 and its worth is $90 \mathrm{~V}$. Yield swell voltage with two phase ILBC is showed up in Fig 9 and its worth is $87.542 \mathrm{~V}$. Yield current however two phase ILBC is showed up in Fig 10 and its worth is $0.17 \mathrm{~A}$. Yield intensity of two phase ILBC is showed up in Fig 11 and its worth is 15.5Watts.

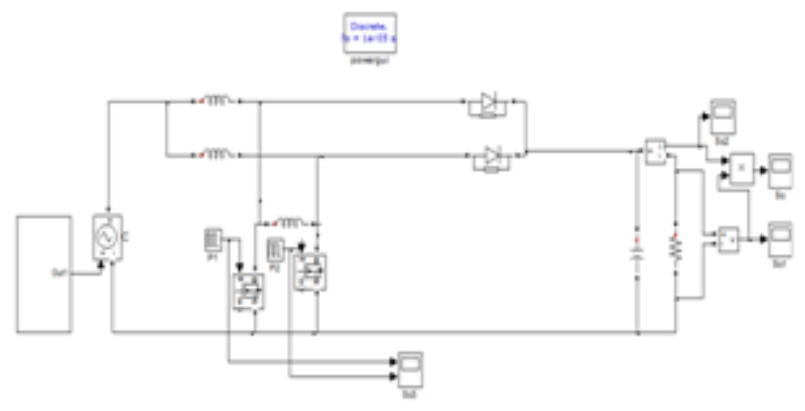

Fig.5 Circuit diagram of the two stage ILBC with ZVT

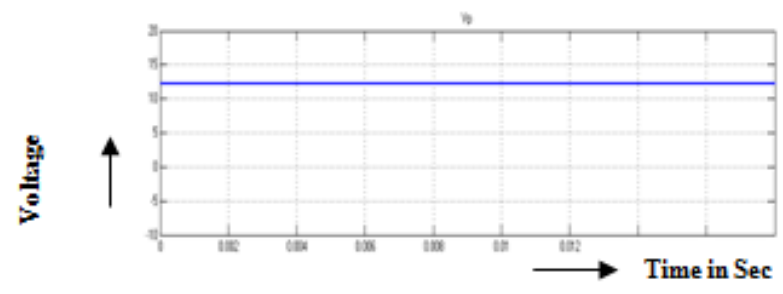

Fig.6 Information voltage crosswise over two phase ILBC

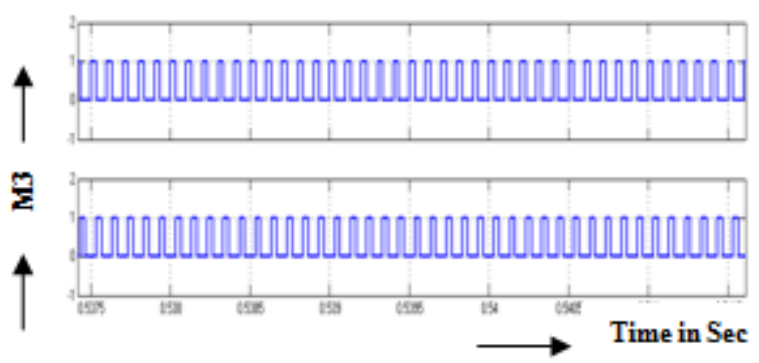

Fig.7 Switching pulse for ILBC (M1,M3) 


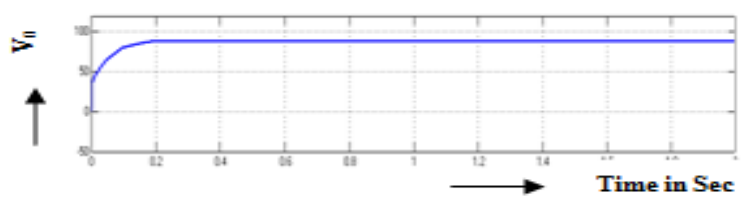

Fig.s Yield voltage crosswise over two phase ILBC

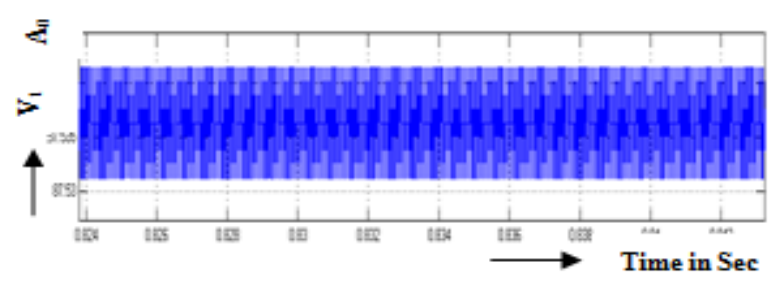

Fig.9 Yield ripple voltage with two stage ILBC

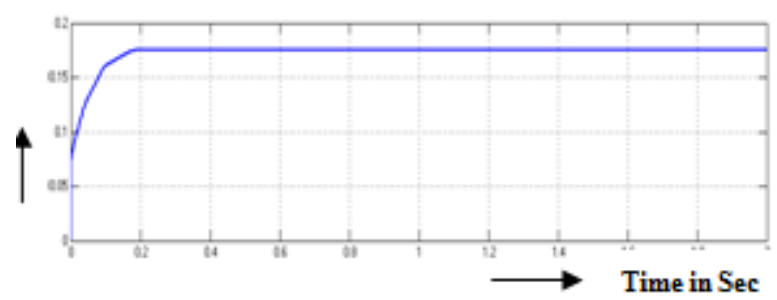

Fig.10 Yield current though two stage ILBC

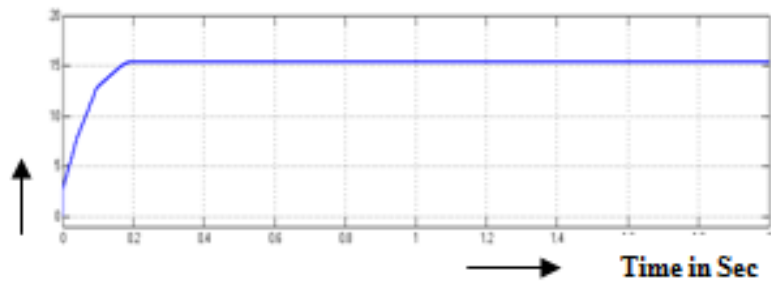

Fig.11 Yield power of two stage ILBC

Interleaved three Stage Boost Converter Fed DC Drive With Zero-Voltage Transition Circuit diagram is appeared in Fig.12. Input voltage across three stage ILBC is appeared in Fig 13 and its value is $12 \mathrm{~V}$. Switching pulse for ILBC M1 and M3 is appeared in Fig 14 and its value is 1V. [14],[ 16], [18]

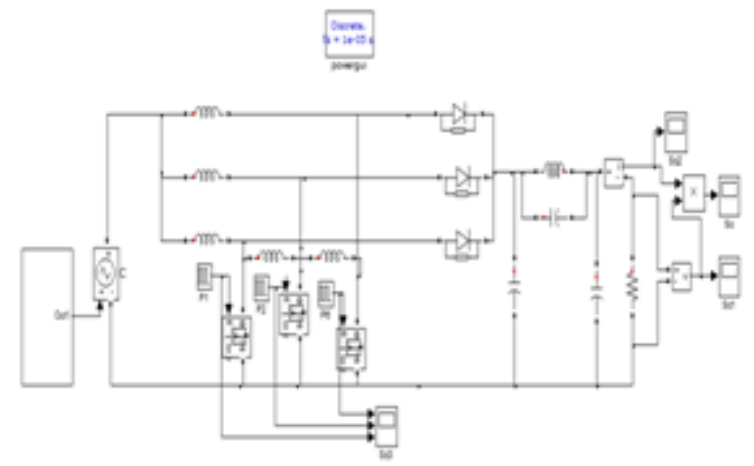

Fig.12 Circuit diagram of the Three stage ILBC with ZVT

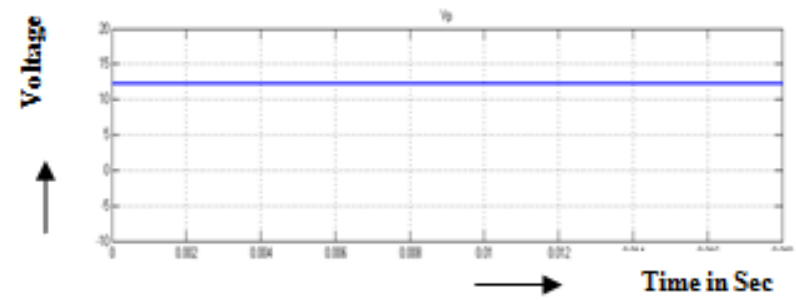

Fig.13 Input voltage across three stage IILBC

$\bar{z}$
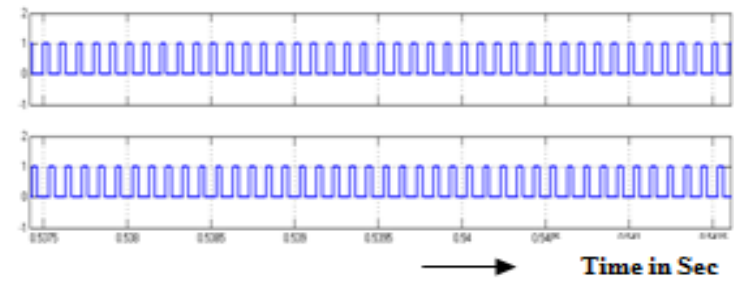

Fig.14 Switching pulse for ILBC (M1, M3)

Yield voltage crosswise over three phase ILBC is showed up in Fig 15 and its worth is $125 \mathrm{~V}$. Yield swell voltage with two phase ILBC is showed up in Fig 16 and its worth is 123.1064V. Yield current however three phase ILBC is showed up in Fig 17 and its worth is $0.25 \mathrm{~A}$. Yield intensity of three phase ILBC is showed up in Fig 18 and its worth is 30Watts

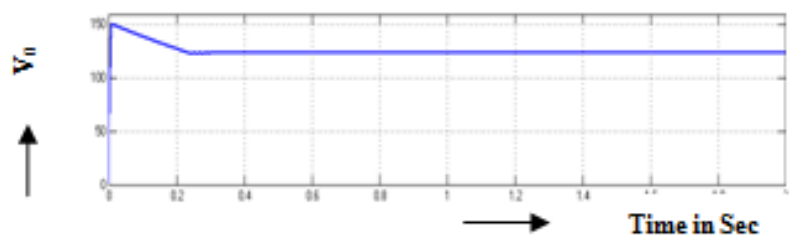

Fig.15 Yield voltage across three stage ILBC 

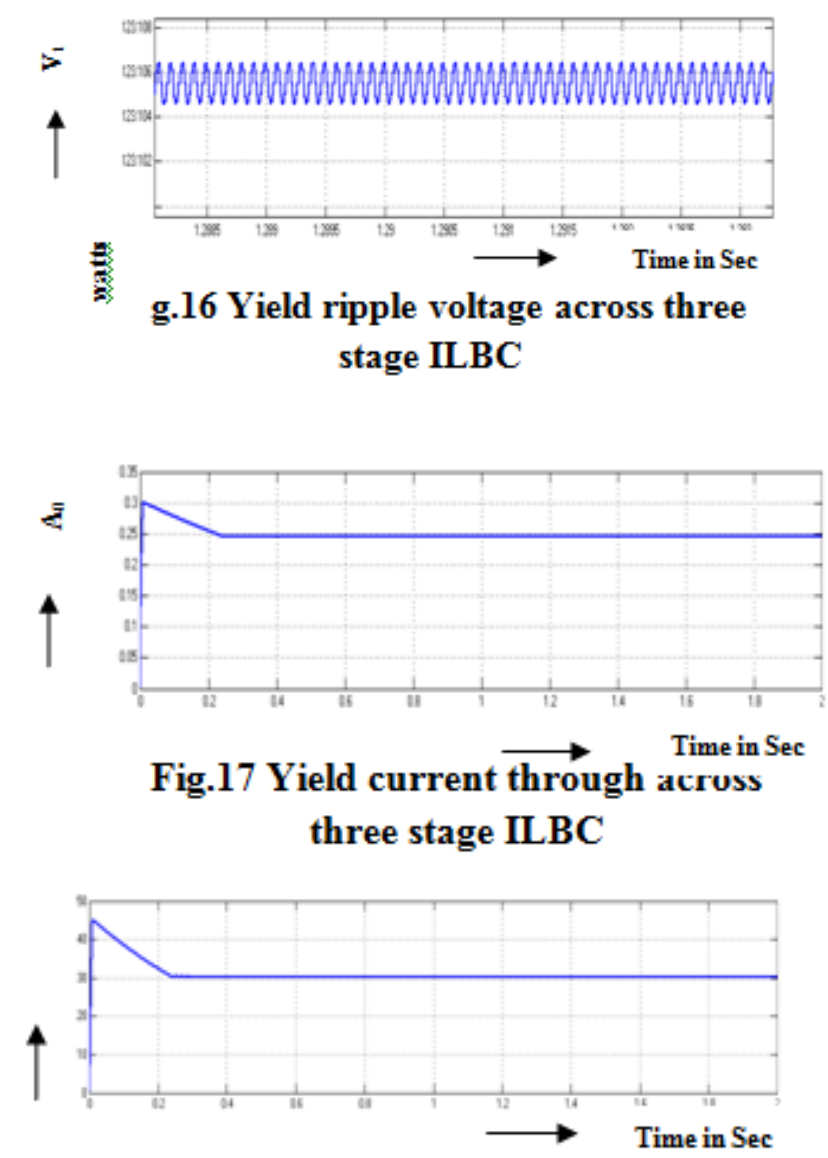

Fig.18 yield power with across three stage ILBC

Table-1 Comparison of output voltage, output ripple voltage \& output power

\begin{tabular}{|c|c|c|c|c|}
\hline ILBC & $\mathbf{V}_{\text {in }}$ & $\mathbf{V}_{\mathbf{o}}$ & $\mathbf{V}_{\mathbf{9 r}}$ & $\mathbf{P}_{\mathbf{o}}$ \\
\hline $\begin{array}{c}2- \\
\text { Stage }\end{array}$ & $12 \mathrm{~V}$ & $87 \mathrm{~V}$ & $0.017 \mathrm{~V}$ & $15.5 \mathrm{~W}$ \\
\hline $\begin{array}{c}3- \\
\text { Stage }\end{array}$ & $12 \mathrm{~V}$ & $123 \mathrm{~V}$ & $0.001 \mathrm{~V}$ & $30 \mathrm{~W}$ \\
\hline
\end{tabular}

\section{Conclusion}

An epic delicate exchanging interleaved coupled-inductor help converter is proposed in this paper. The least difficult helper resounding circuit is exhibited to understand the ZVT turn-on and littler current mood killer properties of the two fundamental switches. The swell voltage in the yield of two-arrange ILBC is $0.017 \mathrm{~V}$. The swell voltage in the yield of three-arrange ILBC is $0.001 \mathrm{~V}$. The power yield in two phase ILBC is $15 \mathrm{~W}$. The power yield in three phase ILBC is $30 \mathrm{~W}$. Hence the exhibition of Three phase ILBC is superior to that of two phase ILBC. [19],[20],[21]

The present work manages reenactment of open circle
ILBC framework. Shut circle ILBC will be explored in future.

\section{REFERENCES}

[1] Sharma, R.K., Irusapparajan, G. \& Periyaazhagar, D. 2019, "Three-phase symmetric cascading Z-source seven levels multilevel inverter excited by multi carrier sinusoidal pulse width modulation scheme", International Journal of Innovative Technology and Exploring Engineering, vol. 8, no. 10, pp. 4269-4274.

[2] Velavan, R., Bharanidharan, S. \& Sheeba, B. 2019, "EMF pollution Causes, effects and protection", International Journal of Innovative Technology and Exploring Engineering, vol. 8, no. 9 Special Issue 3, pp. 1166-1168.

[3] Saravana, S., Balaji, S., Arulselvi, S. \& John Paul Praveen, A. 2019, "Reliable power quality monitoring and protection system", International Journal of Innovative Technology and Exploring Engineering, vol. 8, no. 9 Special Issue 3, pp. 644-645.

[4] Tamil Selvan, S. \& Sundararajan, M. 2019, "Performance Parameters of 3 Value 8t Cntfet Based Sram Cell Design Using H-Spice", International Journal of Recent Technology and Engineering, vol. 8, no. 2 Special issue 5, pp. 22-27.

[5] Jac Fredo, A.R., Abilash, R.S., Femi, R., Mythili, A. \& Kumar, C.S 2019, "Classification of damages in composite images using Zernike moments and support vector machines", Composites Part B: Engineering, vol. 168 , pp. $77-86$.

[6] Kathiravan, P. \& Govindaraju, C. 2019, "Design and evaluation of ultra gain isolated DC-DC converter for photovoltaic system", International Journal of Engineering and Advanced Technology, vol. 8, no. 5, pp. 2646-2651.

[7] Kripa, N., Vasuki, R. \& Kishore Kanna, R. 2019, "Realtime neural interface controlled au-pair BIMA bot", International Journal of Recent Technology and Engineering, vol. 8, no. 1, pp. 992-994.

[8] Mohanraj, Meenaa Kumari, M., Philomina, S. \& Jasmin, M. 2019, "In-situ humidity measurement of hydrogen fuel cell car using MEMS sensor", International Journal of Recent Technology and Engineering, vol. 8, no. 1, pp. 41-43.

[9] Velmurugan, T. \& Prakash, S. 2019, "Artificial intelligent based distribution automation of swift fault detection isolation and power restoration for HT network", International Journal of Innovative Technology and Exploring Engineering, vol. 8, no. 6, pp. 1-6.

[10] Dwarakesh, K. \& Prem Kumar, G. 2019, "Five-level inverter based sequential boost system using fuzzy logic controller", International Journa of Innovative Technology and Exploring Engineering, vol. 8, no. 6, pp 12-19.

[11] Anne Gifta, A. \& Hemavathi, G. 2019, "Analysis of grid tied solar PV system using ANFIS Algorithm", International Journal of Innovative Technology and Exploring Engineering, vol. 8, no. 6, pp. 312-316.

[12] Jayavel, R., Rangaswamy, T.R. \& Prakash, S. 2019, "Efficient grid management system with renewable and conventional power sources", International Journal of Innovative Technology and Exploring Engineering, vol. 8, no. 6, pp. 287-289.

[13] Hemavathi, G. \& Maheshwaran, S. 2019, "Proportional resonant controlled high gain step-up converter system with improved response", International Journal of Innovative Technology and Exploring Engineering, vol. 8, no. 6, pp. 317-323.

[14] Periyaazhagar, D. \& Irusapparajan, G. 2019, "Design and completion of asymmetric single phase 27 level cascaded mli for various pwm scheme", International Journal of Innovative Technology and Exploring Engineering, vol. 8, no. 6, pp. 792-797.

[15] Mahalakshmi, V. \& Vijayaragavan, S.P. 2019, "PV based power electronic converters for high voltage DC applications", International Journal of Recent Technology and Engineering, vol. 7, no. 6, pp. 670-674. 
[16] Irusapparajan, G., Periyaazhagar, D., Prabaharan, N. \& Rini Ann Jerin, A 2019, "Experimental verification of trinary DC source cascaded h-bridge multilevel inverter using unipolar pulse width modulation", Automatika, vol. 60 , no. 1 , pp. $19-27$

[17] Sangeetha, G., Sherine, S., Arputharaju, K. \& Prakash, S. 2019, "On Line Monitoring of Higher Rated Alternator using Automated Generator Capability Curve Administer", Proceedings of the IEEE International Conference on \&amp;quot;Recent Trends in Electrical, Control and Communication\&amp;quot;, RTECC 2018, pp. 176.

[18] Bycil, V.J. \& Wiselin, M.C.J. 2019, "Modeling and analysis of vibration energy harvesting system using piezo stack", International Journal of Mechanical and Production Engineering Research and Development, vol. 9, no. Special Issue 1, pp. 523-533.

[19] Sripada, A., Warrier, A., Kapoor, A., Gaur, H. \& Hemalatha, B. 2018 "Dynamic lateral balance of humanoid robots on unstable surfaces", International Conference on Electrical, Electronics, Communication Computer Technologies and Optimization Techniques, ICEECCOT 2017, pp. 539.

[20] Srinivasan, S., Thirumalaivasan, K. \& Sivakumaran, T.S. 2018 , "Performance evaluation of double-output luo converters", Journal of Advanced Research in Dynamical and Control Systems, vol. 10, no. 10 Special Issue, pp. 870-878.

[21] Karthikayen, A. \& Selvakumar Raja, S. 2018, "A skellam distribution inspired trust factor-based selfish node detection technique in MANETs", Journal of Advanced Research in Dynamical and Control Systems, vol. 10 no. 13 , pp. $940-949$.

\section{AUTHORS PROFILE}

S.Aarthi Suriya, Assistant Professor, Department of EEE Bharath Institute of Higher Education and Research, Tamilnadu, India.

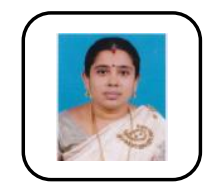

AnithaSampathKumar, Assistant Professor ,Department of EEE, Bharath Institute of Higher Education and Research, Tamilnadu, India.

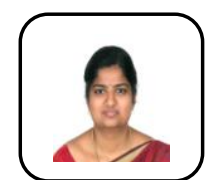

S.Sherine , Assistant Professor Department of EEE, Bharath Institute of Higher Education and Research,

Tamilnadu, India. 